\title{
Penegakan Hukum terhadap Anak sebagai Pelaku Tindak Pidana Percobaan Perkosaan
}

\author{
Melisa Halimatus Sa'diyah \\ Kejaksaan Negeri Banggai \\ Korespondensi: melisa.sadiah@gmail.com
}

\section{Info Artikel \\ Riwayat: \\ Diajukan : 15 April 2021 \\ Ditelaah : : 27 April 2021 \\ Direvisi : 31 Mei 2021 \\ Diterima : 02 Juli 2021}

Kata Kunci :

diversi; penegakan hukum; pelaku anak; percobaan perkosaan

DOI:

10.18196/ijclc.v2i2.12318

\begin{abstract}
Abstrak
Kasus kekerasan seksual selalu bertambah disetiap tahunnya terutama yang melibatkan anak baik sebagai pelaku maupun korban. Percobaan perkosaan merupakan salah satu kekerasan seksual yang sering dilakukan oleh anak. Tidak selesainya perkosaan yang dilakukan oleh anak di pengaruhi oleh banyak faktor. Namun demikian, sekalipun perbuatan tersebut tidak selesai tetap menjadikan anak sebagai pelaku sehingga harus mempertanggungjawabkan perbuatannya melalui mekanisme sistem peradilan pidana anak. Tulisan ini lebih lanjut akan menjelaskan bagaimana proses penegakan hukum dalam tindak pidana percobaan perkosaan yang dilakukan oleh anak. Penelitian ini menggunakan jenis penelitian normatif, dengan pendekatan undangundang dan pendekatan kasus. Untuk melengkapi data, penelitian ini melakukan wawancara terhadap narasumber di Pengadilan Negeri Yogyakarta. Metode pengumpulannya dengan cara melakukan studi pustaka terhadap bahan hukum sekunder, primer, dan tersier. Hasil penelitian menunjukan bahwa anak sebagai pelaku percobaan perkosaan tidak dapat dilakukan upaya diversi dikarenakan ancaman sanksi melebihi batas maksimal, yaitu 7 tahun sebagaimana telah diatur dalam Pasal 7 ayat (2) UU Nomor 11 Tahun 2012 tentang Sistem Peradilan Pidana Anak (SPPA). Pelaku percobaan perkosaan dikenakan Pasal 285 KUHP jo. Pasal 53 KUHP. Meskipun demikian dalam hal penerapan sanksinya tidak boleh melebihi batas maksimal orang dewasa. Hal tersebut sesuai dengan ketentuan Pasal 81 ayat (2) UU Nomor 11 Tahun 2012 tentang SPPA menjelaskan bahwa ancaman pidana terhadap anak adalah separuh atau setengah dari orang dewasa, dari kedua kasus dalam tulisan ini masing-masing jumlah sanksi pidananya berbeda-beda, namun demikian tidak melebihi batas maksimal 4,5 tahun. Lebih lanjut, pertimbangan hakim dalam menjatuhkan sanksi pidana di dasarkan pertimbangan baik secara yuridis maupun non yuridis.
\end{abstract}

\section{Pendahuluan}

Kejahatan yang terjadi di lingkungan masyarakat beraneka ragam, salah satunya yang sering terjadi ialah kejahatan kekerasan, eksploitasi seksual, pelecehan dan perkosaan. ${ }^{1}$ Kekerasan, $^{2}$ penganiayaan hingga perkosaan merupakan perilaku yang keji karena akan memberikan dampak yang cukup besar terhadap korbannya. Ketakutan, trauma, hingga stress akan di alami pihak korban atas perbuatan tersebut. Perkosaan sendiri merupakan jenis tindak pidana kesusilaan yang telah diatur dalam Pasal 285 Kitab Undang-Undang Hukum Pidana (KUHP). Selain itu, dalam Pasal 81 Undang-Undang No.23 Tahun 2002 juga mengatur mengenai kekerasan seksual atau perkosaan terhadap anak. Adapun ancaman terhadap tindak pidana perkosaan adalah pidana penjara paling lama dua belas tahun.

$1 \mathrm{Ni}$ Made Dwi Kristiani. 2014. "Kejahatan Kekerasan Seksual (perkosaan) Ditinjau dari Perspektif Kriminologi”. Jurnal Magister Hukum Udayana. Vol.7. No.3, hlm.34 
Perbuatan perkosaan merupakan pelanggaran terhadap Hak Asasi Manusia (HAM) khususnya bagi kaum perempuan. Hak asasi manusia mengatur perlindungan terhadap hak-hak manusia, sehingga sesama manusia tidak diperkenankan untuk mengambil hak-hak orang lain dan kehormatan perempuan harus dilindungi. Tindak pidana perkosaan merupakan suatu perbuatan yang sangat meresahkan, terlebih bagi kaum perempuan karena efek yang diakibatkan oleh perbuatan ini sangatlah besar terhadap korbannya. Perempuan yang menjadi korban akan mengalami trauma yang berkepanjangan. Korban akan mengalami kekerasan baik secara fisik, psikis dan mental. Trauma yang berkepanjangan hingga pengalaman yang buruk seumur hidup dapat membuat korban menjadi stress hingga ingin bunuh diri karena mendapati hal yang mengerikan dan membuat mereka tidak memiliki masa depan lagi.

Perbuatan atau kejahatan dapat terjadi dimana saja dan kapan saja, begitu pun dengan perkosaan. Pelaku tindak kejahatan juga dapat dilakukan oleh siapa saja tanpa kita sadari. Saat ini banyak kita jumpai pelaku dari perbuatan kejahatan tidak hanya dilakukan oleh kalangan dewasa saja, akan tetapi perilaku tersebut juga sudah masuk dalam kalangan anak-anak. Anak yang menjadi pelaku kejahatan memang sangat disayangkan karena anak merupakan penerus bangsa untuk masa depan.

Anak yang melenceng dalam bersikap dan berperilaku biasanya karena beberapa faktor, antara lain dari kebebasan dalam bergaul, perubahan cara hidup orang tua, berkembangnya ilmu teknologi dan informasi, lingkungan bersosial dan lingkungan hidup berkembangnya anak yang telah memberikan dampak negatif yang kemudian membuat perubahan yang menyimpang dengan perilaku anak. ${ }^{2}$ Anak yang kekurangan kasih sayang, perhatian, bimbingan pendidikan dan agama dari orang tua ataupun wali akan lebih mudah masuk dalam lingkungan dan pergaulan masyarakat yang kurang sehat. Padahal anak merupakan karunia dari Allah SWT yang dititipkan kepada orang tua. Sudah seharusnya orang tua membimbing, mengawasi serta memberi petunjuk kepada anak dalam bersikap dan berperilaku. Sehingga orang tua memiliki peran yang sangat penting dalam perkembangan anak.

Anak yang melakukan perbuatan melanggar hukum atau menyimpang dari aturan undangundang akan diproses secara hukum. Hal ini dikarenakan perbuatan atau kejahatan yang dilakukan anak tersebut dapat merugikan orang lain baik secara nyawa maupun mental (korban). Namun tidak semua anak dapat mempertanggungjawabkan perbuatannya, karena terdapat batas minimal usia anak yang dapat mempertanggungjawabkan perbuatannya sesuai dengan undang-undang.

Mengingat usia anak terdapat perbedaan perlakuan dengan orang dewasa ketika anak berhadapan dengan hukum. Hal tersebut sebagai wujud perlindungan yang diberikan kepada anak. Adanya pelindungan kepada anak ditujukan untuk tidak menghilangkan kemerdekaan anak dalam tumbuh dan berkembang sekalipun mereka sebagai pelaku pidana. Para penegak hukum dalam menyelesaikan atau memproses perkara anak baik dalam tahap kepolisian, kejaksaan, persidangan harus sesuai dengan aturan yang ada dengan menjunjung nilai keadilan. Memberikan hak-hak anak dan tidak memberikan tekanan yang keras selama proses pemeriksaan hingga penuntutan merupakan beberapa bentuk perlindungan terhadap anak yang berhadapan dengan hukum.

Penyelesaian perkara anak sudah menjadi tugas dan wewenang aparat penegak hukum untuk memproses, menyelesaikan secara adil, memberikan efek jera terhadap pelaku dengan mempertimbangkan pihak korban yang mengalami dampak dan akibat dari perbuatan pelaku, pihak korban dapat mengalami traumatik secara psikis maupun fisik atas perbuatan tindak pidana kekerasan seksual. Dengan adanya sanksi kepada pelaku atas perbuatan yang melanggar hukum diharapkan dapat mengurangi peristiwa dan atau perbuatan melanggar hukum yang dilakukan oleh anak, dengan pemberian sanksi, arahan, dan bimbingan.

Hukum pidana tidak hanya dapat menjerat seseorang yang berniat atau merencanakan terlebih dahulu untuk melakukan tindak kejahatan, tetapi juga dapat menjerat perbuatan yang tidak selesai atau tujuannya tidak terpenuhi untuk melakukan tindak pidana karena sudah memiliki niatan untuk melakukan tindak kejahatan. Perbuatan tersebut dikenal sebagai percobaan sebagaimana yang terdapat dalam ketentuan Pasal 53 KUHP, dimana percobaan melakukan kejahatan pidana, niat yang datang dari diri sendiri dan telah memulai melaksanakan suatu perbuatannya akan tetapi usaha dan tujuannya untuk melakukan perbuatan pidana tidak selesai atau tidak terpenuhi. Meskipun demikian sanksi dalam

2 Tri Wahyu Widiastuti. 2016. "Penegakan Hukum Terhadap Kenakalan Anak”. Journal UNISRI. Vol.1 hlm. 
perbuatan percobaan melakukan tindak pidana, akan dikurangi sepertiga dari kejahatan yang dilakukannya.

Penulis akan mengerucut pada pembahasan mengenai analisa penegakan hukum terhadap putusan pengadilan dalam kasus pidana percobaan perkosaan yang mana pelakunya adalah seorang anak yang masih dibawah umur. Terdapat dua putusan pengadilan yang akan penulis analisis yaitu Putusan Pengadilan Negeri Tembilahan Nomor. 5/Pid.Sus-Anak/2014/PN.Tbh, dan Putusan Pengadilan Negeri Maros Nomor. 82/Pid.B/2014/PN.Mrs. Berdasarkan uraian di atas, maka penulis ingin melihat bagaimana proses penegakan hukum terhadap tindak pidana percobaan perkosaan yang dilakukan oleh anak.

\section{Metode Penelitian}

Penulisan ini menggunakan penelitian hukum normatif dengan berdasarkan pada produk hukum, seperti mengkaji undang-undang. Penelitian ini dilakukan dengan pendekatan perundangundangan dan pendekatan kasus. Guna melengkapi bahan hukum untuk penelitian ini, narasumber dalam penelitian ini yaitu:

a. Hakim (Pidana Umum) Pengadilan Negeri Yogyakarta yaitu Asep Pernama, S.H

b. Hakim (Pidana Anak) Pengadilan Negeri Yogyakarta yaitu Taufik Rahman, S.H

Semua data-data yang sudah terkumpul selama proses penelitian dimulai dari bahan hukum sekunder hingga dokumen-dokumen yang terkait dilakukan dengan cara metode pendekatan deskriptif. Pendekatan deskriptif ini dilakukan dengan menyusun data, pembahasan, dan pengelompokkan ke dalam bagian-bagian tertentu yang kemudian dianalisis untuk diolah menjadi data informasi dalam penelitian ini.

\section{Hasil dan Pembahasan}

\subsection{Kajian Teoritik tentang Penegakan Hukum}

Pada umumnya masyarakat memandang penegakan hukum secara sempit, yaitu terkait penegakan hukum dalam arti menegakan hukum atau undang-undang. Dalam hal ini, sifat penegakan hukum adalah untuk melaksanakan atau menerapkan hukum tersebut. Apabila telah sesuai dengan undang-undang maka penegakan hukum dianggap telah berhasil. Pendapat itu dikatakan sempit, karena pada dasarnya keberhasilan penegakan hukum tidak hanya terpenuhi pada faktor penegak hukum dan undang-undang saja, tetapi juga terpenuhinya sarana dan prasarana penegakan hukum serta kesadaran hukum masyarakat. ${ }^{3}$

Penegakan hukum sendiri merupakan suatu rangkaian langkah aparat penegak hukum dalam melakukan penindakan hukum terhadap setiap tindakan atau peristiwa pelanggaran melawan hukum. ${ }^{4}$ Menurut Soerjono Soekanto, penegakan hukum adalah kegiatan menyesuaikan hubungan nilai-nilai yang telah dijabarkan dalam kaidah-kaidah atau pandangan nilai dan mewujudkan sikap sebagai rangkaian penjabaran nilai pada tahap akhir untuk menciptakan, memelihara, dan mempertahankan kedamaian pergaulan hidup. ${ }^{5}$

Menurut Jimmly Asshiddie, penegakan hukum ditinjau dari sudut objeknya yaitu dari segi hukumnya. Lebih lanjut, penegakan hukum juga memiliki arti yang luas dan sempit. Dalam arti luas, penegakan hukum mencakup nilai-nilai keadilan yang didalamnya terkandung aturan formal maupun

3 Bambang Waluyo. 2016. Penegakan Hukum Di Indonesia. Jakarta Timur: Sinar Grafika, hlm.63 4 Theodorus Yosep Parera. 2016. Advokat Dan Penegak Hukum. Yogyakarta: Genta. hlm.15

5 Soerjono Soekanto. 2012. Faktor-Faktor Yang Mempengaruhi Penegakan Hukum. Jakarta: Raja Grafindo Persada, hlm.5 
nilai-nilai keadilan dalam masyarakat. Dalam arti sempit, penegakan hukum hanya mencakup penegakan aturan yang formal dan tertulis saja. ${ }^{6}$

Secara konkret penegakan hukum adalah berlakunya hukum positif yang dalam praktiknya sudah seharusnya patut untuk dipatuhi. Dalam hal ini, memberikan keadilan dalam menyelesaikan suatu perkara berarti memutuskan hukum in concreto untuk mempertahankan dan menjamin di taatinya hukum materiil dengan menggunakan prosedural yang telah ditetapkan hukum formal. ${ }^{7}$ Secara objektif, penegakan hukum ialah norma yang hendak ditegakkan mencakup pengertian hukum formal dan materiil. Dimana hukum formal berkaitan dengan peraturan perundang-undangan yang tertulis, sedangkan hukum materiil mencakup segala pengertian nilai-nilai keadilan yang hidup dalam masyarakat. Dalam hal ini, dengan maksud menegaskan bahwa hukum yang harus ditegakkan tidak hanya norma aturan itu sendiri melainkan juga dengan nilai-nilai keadilan yang terkandung didalamnya. ${ }^{8}$

Terkait dengan aturan hukum, muncul beberapa persoalan dengan hal substansi atau aturan hukum itu sendiri, antara lain: apakah sudah tersedia mengenai peraturan-peraturan yang dibutuhkan, apakah redaksi dan rumusan dalam aturan sudah tegas dan cukup jelas. Menurut Van Doorn tujuantujuan yang dirumuskan dalam aturan-aturan penegakan hukum masih tidak jelas atau kabur, sehingga menimbulkan terjadinya perbedaan penafsiran dalam pelaksanaannya yang dapat menambahkan/mengurangi sendiri dalam konteks situasi yang ia hadapi. ${ }^{9}$ Kemudian persoalan lain seperti apakah tidak terjadi pertentangan atau kontradiksi dan overlapping dengan peraturan yang lain, apakah terdapat sanksi yang sepadan atau sesuai dengan tindak yang melakukan perbuatan melanggar hukum, dan apakah peraturan yang ada masih sesuai tidak dengan perkembangan masyarakat dan sosial.

Penegakan hukum pidana memiliki arti sendiri, yaitu suatu proses aparat penegak hukum pidana melakukan tindakan memeriksa seseorang yang diduga melakukan suatu perbuatan kejahatan atau melanggar hukum dengan tujuan untuk memastikan seseorang tersebut bersalah atau tidaknya secara hukum. Pemeriksaan yang dilakukan aparat penegak hukum dimulai dengan melakukan penyelidikan dan penyidikan, kemudian penuntutan, sampai pada tahap penjatuhan atau penentuan hukuman, proses ini disebut sebagai proses peradilan pidana. ${ }^{10}$

Sistem peradilan pidana di dalamnya terdapat subsistem pendukung, yaitu kepolisian, kejaksaan, pengadilan, lembaga kemasyarakatan.11 Para aparat penegak hukum memiliki tugas-tugas dan kewenangan sendiri-sendiri. Kepolisian bertanggungjawab pada tahap penyelidikan/penyidikan, kejaksaan bertanggungjawab pada tahap penuntutan, dan pada tahap penentuan hukum bersalah atau tidaknya seseorang adalah tanggungjawab dari pengadilan.

Penegakan hukum pidana ini sasarannya pada peristiwa kejahatan, melakukan penanggulangan dengan cara memberikan sanksi atau hukuman terhadap seseorang yang bersalah atau telah melakukan tindak kejahatan. Satjipto Rahardjo sebagaimana yang dikutip oleh Nyoman Serikat Putra Jaya mengatakan, bahwa proses penegakan hukum itu menjangkau pula sampai dengan tahapan pembuatan hukum atau undang-undang, perumusan pikiran pembuat undang-undang yang dituangkan dalam peraturan perundang-undangan akan turut menentukan bagaimana penegakan hukum itu nanti dijalankan. ${ }^{12}$

Proses dalam melaksanakan penegakan hukum yaitu peradilan merupakan salah satu institusi penegakan hukum. Aktivitas atau kegiatan didalamnya tidak terlepas dari hukum yang telah dibuat dan disediakan oleh badan pembuat hukum itu. Akan tetapi ada perbedaan mengenai peradilan dan

6 Muhammad Alvin. 2017. Dalam Skripsi berjudul "Penegakan HukumTerhadap Tindak Pidana Penyalahgunaan Narkotika Oleh Anak Dibawah Umur Di Kota YogyakartaTahun 2014", UIN Yogyakarta, hlm. 13

7 Delyana Sahnt. 2004. Konsep Penegakan Hukum. Yogyakarta: Liberty, edisi cetak ulang, hlm.32

8 Muhammad Alvin, Op. Cit. hlm. 14

9 Satjipto Rahardjo. 1980. Hukum, Masyarakat, dan Pembangunan. Bandung: Alumni, hlm. 74.

10 Romli Atmasasmita. 2000. Sistem Peradilan Pidana: Prespektif Eksistensialisme dan Abolisionisme. Bandung: Binacipta (edisi cetak ulang), hlm.14

11 Rusli Muhammad. 2011. Sistem Peradilan Pidana Indonesia. Yogyakarta: UII Press Yogyakarta. hlm. 13 12 Nyoman Sarikat Putra Jaya. 2005. Kapita Selektra Hukum Pidana. Semarang: Badan Penerbit Undip, hlm. 23 
pengadilan, peradilan mengarah pada proses mengadili perkara, sedangkan pengadilan merupakan salah satu lembaga dalam proses tersebut, lembaga-lembaga yang dimaksud ialah kepolisian, kejaksaan dan advokat. ${ }^{13}$ Keterlibatan lembaga-lembaga dalam proses peradilan secara penuh hanya terjadi pada saat mengadili perkara pidana.

Penegakan hukum dalam kenyataan sehari-hari berhubungan dengan struktur masyarakat, yang keduanya saling berpengaruh kuat terhadap cara-cara penegakan hukum suatu negara. Indonesia sebagai negara modern memiliki ciri-ciri sebagai berikut: ${ }^{14}$

1. Adanya UUD dalam bentuk yang tertulis.

2. Hukum itu berlaku untuk wilayah negara.

3. Hukum merupakan sarana yang dipakai secara sadar untuk mewujudkan keputusan-keputusan politik masyarakatnya.

4. Menurut Max Weber cara penegakan hukum pada suatu masa berbeda dengan masa yang sebelumnya yang tentunya tidak terlepas dari dominasi yang disebabkan karena keadaan masyarakatnya yang berbeda, dimana tatanan kehidupan masyarakatnya menurut Hart dalam Satjipto Rahardjo didasarkan Secondary Rules Obligation dimana masyarakatnya mempunyai kehidupan yang terbuka, luas, dan komplek seperti saat ini maka terdapat diferensiasi dan institusionalisasi pekerjaan hukum berupa:
a. Rules of recognition.
b. Rules of change; dan
c. Rules of adjudication.

Ruang lingkup penegakan hukum sebenarnya sangat luas, mencakup hal-hal yang langsung dan tidak langsung terhadap orang terjun dalam bidang penegakan hukum. Menurut Josep Golstein, membedakan penegakan hukum pidana menjadi tiga bagian, yaitu: ${ }^{15}$

1. Total enforcement, yakni ruang lingkup penegakan hukum pidana sebagaimana yang dirumuskan oleh hukum pidana substantif (substantive law of crime). Penegakan hukum secara total ini tidak mungkin dilakukan sebab para penegak hukum dibatasi secara ketat oleh hukum acara pidana yang antara lain mencakup aturan-aturan penangkapan, penahanan, penggeledahan, penyitaan dan pemeriksaan pendahuluan. Disamping itu, mungkin terjadi hukum pidana substantif sendiri memberikan batasan-batasan, misalnya dibutuhkan aduan terlebih dahulu sebagai syarat penuntutan pada delik-delik aduan (klacht delicten). Ruang lingkup yang dibatasi ialah sebagai area of no enforcement.

2. Full enforcement, setelah ruang lingkup penegakan hukum pidana yang bersifat total tersebut dikurangi area of no enforcement dalam penegakan hukum ini para penegak hukum diharapkan dapat dilakukan secara maksimal;

3. Actual enforcement, dianggap not a realistic expectation, sebab adanya keterbatasan-keterbatasan dalam bentuk waktu, personil, alat-alat investigasi, dan sebagainya, yang keseluruhannya mengakibatkan keharusan dilakukan discretion dan sisanya inilah yang disebut actual enforcement.

Menurut Muladi, sebagai suatu proses yang bersifat sistematik, maka penerapan penegakan hukum haruslah dipandang dari 3 dimensi, antara lain:16

1. Penerapan hukum dipandang sebagai system normative yaitu penerapan keseluruhan aturan hukum yang menggambarkan nilai-nilai sosial di dukung oleh sanksi pidana;

13 Sanyoto. 2008. “Penegakan Hukum Di Indonesia”. Jurnal Dinamika Hukum. Vol.8. No.3, hlm.200 14 Ibid, hlm. 203

15 M. Husein Maruapey. 2017. "Penegakan Hukum dan Perlindungan Negara". Jurnal Ilmu Politik dan Komunikasi. Vol. 7. No.1, hlm. 24

16 Ibid, hlm. 25 
2. Penerapan hukum dipandang sebagai system administrative yang mencakup interaksi antar aparatur penegak hukum yang merupakan sub-sistem peradilan di atas;

3. Penerapan hukum pidana merupakan system social, artinya bahwa dalam mendefinisikan tindak pidana harus pula diperhitungkan berbagai perspektif pemikiran yang ada dalam lapisan masyarakat. Sehubungan dengan berbagai dimensi di atas dapat dikatakan bahwa sebenarnya hasil penerapan hukum pidana harus menggambarkan keseluruhan hasil interaksi antara hukum, praktek administratif dan pelaku sosial.

\subsection{Penegakan Hukum Terhadap Anak Sebagai Pelaku Tindak Pidana Percobaan Perkosaan}

Perkosaan merupakan salah satu bentuk kejahatan kekerasan seksual dan bentuk perilaku yang sangat keji, kejam, dan tidak bermoral. Selain melanggar HAM, kejahatan ini juga mengakibatkan derita fisik, psikologis, dan sosial bagi korban. Pelaku kejahatan hingga peristiwa kejahatan ini dapat terjadi dimana saja dan kapan saja, tanpa bisa diprediksi. Sasaran para pelaku kebanyakan dari kalangan perempuan hingga anak-anak. Para pelaku kejahatan ini menggunakan cara apapun demi mencapai tujuannya, dengan memaksa korban hingga melakukan kekerasan fisik terhadap korban agar korban mau melakukan apa yang pelaku inginkan.

Kejahatan ini tidak dapat dipandang sederhana dan sepele, karena tindakan ini sudah sangat membahayakan dan meresahkan masyarakat khususnya bagi kaum perempuan. Meskipun pemerintah sudah mengatur mengenai aturan hukum mengenai kejahatan kekerasan seksual atau perkosaan, akan tetapi dalam lingkungan hidup masyarakat masih banyak perkara mengenai perempuan dan anak yang menjadi korban kejahatan ini. Apalagi diketahui bahwa pelaku dari tindak kejahatan seksual ini tidak hanya dari kalangan orang dewasa saja melainkan juga anak yang masih dibawah umur. Hal ini membuktikan adanya kesewenang-wenangan diri manusia yang seharusnya menghormati dan melindungi hak-hak sesama, terkhusus terhadap perempuan.

Pelaku kejahatan seksual memiliki unsur paksaan, maka jelas dalam perkosaan merupakan perbuatan yang dilakukan dengan sengaja. Dapat dikatakan tindakan perkosaan apabila telah terjadi persetubuhan anatara pelaku dengan korban. Apabila tidak sampai terjadi persetubuhan maka perbuatan ini dapat dikualifikasikan dengan tindak pidana percobaan perkosaan sebagaimana pada Pasal 53 jo. Pasal 285 KUHP. Percobaan yang dimaksudkan ialah seorang pelaku yang sudah memiliki niat akan tetapi tidak dapat menyelesaikan tujuannya, hal ini bisa terjadi karena adanya penghalang yang bukan dari diri pelaku yang mengakibatkan tujuan itu tidak tercapai.

Seorang anak yang melakukan tindak pidana tetap akan dilakukan proses hukum sebagaimana ketentuan dalam Undang-Undang Nomor 11 Tahun 2012 tentang Sistem Peradilan Pidana Anak (UU SPPA) yang didalamnya berisikan mengenai aturan dan mekanisme peradilan anak yang berhadapan dengan hukum. Anak yang berkonflik dengan hukum dalam Pasal 1 ayat (3) UU SPPA, diartikan sebagai seseorang yang telah berusia 12 (dua belas) tahun, tetapi belum berumur 18 (delapan belas) tahun yang diduga melakukan tindak pidana.

Berdasarkan hasil wawancara dengan Asep Permana, S.H, seorang anak yang menjadi pelaku tindak pidana percobaan perkosaan akan tetap diproses hukum, dilihat dari delik atau perbuatan seorang anak tersebut yang mana perbuatannya merupakan pelanggaran terhadap undang-undang. Penegak hukum tentu juga melihat dari sudut pandang korban yang telah dirugikan. Selain itu lingkungan masyarakat juga menjadi faktor penegak hukum untuk melakukan proses dan tindakan yang adil terhadap pelaku. Hal ini juga dengan tujuan untuk menyadarkan masyarakat untuk tidak melakukan tindakan kejahatan atau melakukan tindak pidana percobaan perkosaan, karena setiap perbuatan yang melanggar hukum akan diselesaikan secara hukum sesuai dengan aturan yang ada. ${ }^{17}$

Anak yang melakukan tindak pidana akan diupayakan diversi terlebih dahulu dalam menyelesaikan perkaranya. Hal tersebut di dasarkan pada ketentuan Pasal 7 ayat (2) huruf a UU No. 11 Tahun 2012 tentang Sistem Peradilan Pidana Anak yang berbunyi: "Diversi sebagaimana dimaksud pada ayat (1) dilaksanakan dalam hal tindak pidana yang dilakukan: (a) di ancam dengan pidana penjara di bawah 7 (tujuh); dan (b) bukan merupakan pengulangan tindak pidana." Pada kasus tindak pidana

17 Wawancara dengan Asep Pernama, Hakim Pengadilan Negeri Yogyakarta, Jumat 08 Februari 2019, 10.00 WIB. 
percobaan perkosaan, Pasal yang dikenakan ialah Pasal 285 KUHP yang mana ancaman pidananya diatas 7 (tujuh) tahun penjara. Sehingga anak sebagai terdakwa dalam tindak pidana percobaan perkosaan tidak dapat dilakukan proses diversi, karena sudah jelas tidak memenuhi syarat sebagaimana pada point a Pasal 7 ayat (1). Apabila diversi tidak dilakukan, maka akan dilanjutkan ke proses persidangan.

Perkosaan diatur di dalam KUHP pada Pasal 285 yang menyebutkan bahwa barang siapa dengan kekerasan atau ancaman kekerasan memaksa seorang wanita bersetubuh dengan dia di luar pernikahan, diancam karena melakukan perkosaan dengan pidana penjara paling lama 12 (dua belas) tahun. Dalam hal tindak pidana perkosaan yang dilakukan oleh anak maka ancaman hukuman yang dijatuhkan adalah separuh dari ancaman pidana penjara terhadap orang dewasa. Karena ancaman dalam Pasal 285 KUHP adalah maksimal 12 (dua belas) tahun penjara, maka hakim menjatuhkan maksimal setengah dari 12 (dua belas) tahun. Artinya anak dijatuhi hukuman tidak lebih dari 6 tahun penjara karena Undangundang Sistem Peradilan Pidana Anak telah mengatur setengah dari ancaman orang dewasa. ${ }^{18}$

Percobaan diatur di dalam Pasal 53 KUHP yang menyebutkan bahwa mencoba melakukan kejahatan dipidana, dimulai dari adanya permulaan pelaksanaan, dan tidak selesainya pelaksanaan itu bukan semata-mata disebabkan karena kehendaknya sendiri. Sehingga penerapan sanksi dalam hal percobaan dikurangi sepertiga dari maksimum pidana pokok. Jika seorang melakukan pidana percobaan perkosaan akan dikenakan ketentuan Pasal 285 KUHP jo. Pasal 53 KUHP yang ancamannya maksimal 12 (dua belas) tahun dikurangi $1 / 3$ (sepertiga) nya. Maka ancaman maksimal yang dapat dikenakan bagi pelaku percobaan perkosaan ialah 9 (delapan) tahun. Jika yang melakukan percobaan perkosaan adalah anak-anak maka hukuman maksimalnya ialah 4,5 tahun dan tidak lebih dari itu karena UU SPPA telah mengatur bahwa hukuman anak ialah setengah dari ancaman orang dewasa. ${ }^{19}$

Berdasarkan hasil penelitian yang dipaparkan oleh penulis di atas maka penegakan hukum terhadap anak yang melakukan tindak pidana percobaan perkosaan akan tetap dilakukan proses hukum dan dikenakan Pasal 285 KUHP jo. Pasal 53 KUHP dengan ancaman hukuman maksimalnya 4,5 tahun. Berikut beberapa kasus anak sebagai pelaku tindak pidana percobaan perkosaan, yaitu :

Tabel. 1

\begin{tabular}{lllll}
\hline No. & \multicolumn{1}{c}{ Putusan Pengadilan } & Pelaku & Korban & \multicolumn{1}{c}{ Sanksi } \\
\hline 1 & $\begin{array}{l}\text { Putusan Pengadilan Negeri } \\
\text { Tembilahan Nomor 5/Pid.Sus- } \\
\text { Anak/2014/PN.Tbh }\end{array}$ & Angga & Hepy & $\begin{array}{l}\text { Pidana penjara selama 2 } \\
\text { (dua) tahun 6 (enam) bulan }\end{array}$ \\
2 & $\begin{array}{l}\text { Putusan Pengadilan Negeri } \\
\text { Maros Nomor } \\
\text { 82/Pid.B/2014/PN.Mrs }\end{array}$ & $\begin{array}{l}\text { Suhartanto } \\
\text { (16 tahun) }\end{array}$ & Nurani & $\begin{array}{l}\text { Pidana penjara selama 4 } \\
\text { (empat) bulan }\end{array}$ \\
\hline
\end{tabular}

Dari data tabel. 1 maka dapat dianalisis sebagai berikut :

1. Putusan Pengadilan Negeri Tembilahan Nomor. 5/Pid.Sus-Anak/2014/PN.Tbh.

Pada kasus pertama Putusan Nomor. 5/Pid.Sus-Anak/2014/PN.Tbh terdakwa Angga Saputra alias Angga Bin Kamarudin dijatuhi sanksi Pidana Penjara selama 2 (dua) tahun 6 (enam) bulan. Perbuatan terdakwa terbukti secara sah dan meyakinkan melanggar ketentuan Pasal 285 KUHP jo. Pasal 53 ayat (1) KUHP Jo UU RI Nomor 11 Tahun 2012 tentang SPPA yang mana terdapat unsur-unsur sebagai berikut:

a. Barang siapa yaitu terdakwa Angga Saputra alias Angga Bin Kamarudin

b. Dengan kekerasan atau ancaman kekerasan yang dilakukan oleh terdakwa dengan bersamasama dengan temannya yang saling berkerjasama menahan dan memaksa korban untuk mengikuti apa yang mereka inginkan.

18 Wawancara dengan Taufik Rahman, Hakim Pengadilan Negeri Yogyakarta, Jumat 08 Februari 2019, 09.00 WIB

19 Ibid 
c. Memaksa perempuan yang bukan isterinya bersetubuh dengan dia yaitu ketika terdakwa memegang tangan saksi korban sehingga tidak berdaya lalu meraba perut dan meremas-remas payudara dengan maksud untuk menyetubuhi saksi korban secara bergiliran dengan terdakwa lainnya.

d. Percobaan yaitu ketika terdakwa tidak selesai melakukan perkosaan karena diperintahkan salah satu teman lainnya untuk mengambil sepeda motor yang tertinggal namun saat kembali ke tempat kejadian korban telah pergi bersama dengan teman lainnya. Sehingga terdakwa tidak selesai dalam mencapai keinginnanya semata-mata bukan karena kehendaknya sendiri.

Selain telah memenuhi unsur-unsur tersebut, hakim juga memiliki beberapa pertimbanganpertimbangan antara lain:

a. Hakim mempertimbangkan laporan penelitian kemasyarakatan dari Pembimbing Kemasyarakatan (BAPAS) sebelum menjatuhkan perkara.

b. Hakim tidak sependapat dengan saran-saran dari Pembimbing Kemasyarakatan (PK) karena perbuatan terdakwa anak mengakibatkan hilangnya masa depan korban dan dengan tetap memperhatikan saran-saran lainnya

c. Hakim berpendapat bahwa pemidanaan yang akan dijalankan oleh terdakwa anak adalah bersifat preventif yaitu sebagai pencegah agar tidak terjadi tindak pidana serupa oleh masyarakat, sedangkan dari segi edukatifnya ialah bagi terpidana anak agar menyadari kesalahan, memperbaiki diri dan tidak mengulangi perbuatannya lagi.

d. Karena terdawa perkara ini ialah anak, hakim mempertimbangkan hukuman yang akan dijalani terdakwa akan dikurangi seluruhnya dari masa tahanan yang telah dijalani terdakwa, sesuai ketentuan Pasal 22 ayat (4) KUHP.

e. Hakim mempertimbangkan hal-hal yang memberatkan dan hal-hal yang meringankan dari perbuatan terdakwa anak tersebut. Salah satu hal yang memberatkan ialah Saksi korban mengalami trauma seumur hidupnya, dan salah satu hal yang meringankan yaitu terdakwa anak mengakui terus terang dan menyesali perbuatannya dan berjanji tidak akan mengulangi lagi didepan persidangan.

Penerapan sanksi pidana pada Putusan Nomor. 5/Pid.Sus-Anak/2014/PN.Tbh secara normatif telah sesuai dengan ketentuan Pasal 285 KUHP jo. 53 ayat (1) KUHP Jo Undang-Undang Nomor. 11 Tahun 2012 tentang Sistem Peradilan Pidana Anak. Hakim dalam merumuskan Pasal-pasal yang diajukan oleh Penuntut Umum dalam kasus tersebut sudah cukup baik. Tindak pidana yang dilakukan oleh terdakwa telah memenuhi unsur-unsur dalam Pasal 285 KUHP jo. Pasal 53 ayat (1) jo. UU No.11 Tahun 2012 tentang SPPA.

Hakim dalam Penjatuhan sanksi pidana penjara terhadap terdakwa tidak sependapat dengan tuntutan Penuntut Umum, yaitu Hakim menjatuhkan pidana penjara selama 2 (dua) tahun dan 6 (enam) bulan, sedangkan Penuntut Umum menjatuhkan pidana 3 (tiga) tahun dan 6 (enam) bulan. Artinya hakim memutuskan sanksi pidana lebih ringan 1 (satu) tahun dari tuntutan Penuntut Umum. Hal ini tentu tidak terlepas dari pertimbangan-pertimbangan Hakim baik secara yuridis maupun non yuridis. Berikut uraian pertimbangan hakim mengenai Putusan Nomor. 5/Pid.Sus-Anak/2014/PN.Tbh, dijelaskan sebagai berikut:

1) Pertimbangan Yuridis

Pertimbangan yuridis oleh Hakim terhadap Putusan Nomor. 5/Pid.Sus-Anak/2014/PN.Tbh sebagai berikut:

a) Dakwaan penuntut umum;

b) Keterangan terdakwa;

c) Keterangan saksi;

d) Barang-barang bukti; dan

e) Pasal-Pasal dalam peraturan hukum pidana. 
Pertimbangan yuridis sebagaimana yang telah disebutkan di atas telah termuat dalam pertimbangan hakim dalam Putusan Nomor. 5/Pid.Sus-Anak/2014/PN.Tbh. Berdasarkan pertimbangan yuridis di atas, Hakim menjatuhkan sanksi pidana penjara 2 (dua) tahun dan 6 (enam) bulan. Dilihat dari ancaman hukuman pidana percobaan perkosaan ialah 9 (Sembilan) tahun karena telah dikurangi dari $1 / 3$ (sepertiga) ancaman maksimal pidana perkosaan. Karena terdakwa masih anak-anak maka maksimal pidana penjaranya ialah $1 / 2$ (setengah) dari ancaman hukuman orang dewasa, artinya hukuman maksimal bagi anak yang melakukan tindak pidana percobaan perkosaan ialah 4,5 tahun. Berarti dalam hal ini, sanksi pidana yang dijatuhkan kepada terdakwa Angga tersebut sudah sesuai dengan aturan yang tidak melebihi sanksi pidana maksimal.

2) Pertimbangan Non Yuridis antara lain :

Pertimbangan non yuridis terhadap Putusan Nomor. 5/Pid.Sus-Anak/2014/PN.Tbh

3) Latar belakang terdakwa

Terdakwa melakukan tindak pidana ini karena pengaruh buruk dalam pergaulan dan pemberian pendidikan formal ataupun non formal yang tidak maksimal.

a) Kondisi terdakwa

Terdakwa adalah seorang anak yang masih dibawah umur. Terdakwa mengakui kesalahannya dan terus terang dan menyesali perbuatannya. Mengenai status sosial terdakwa dikenal sebagai anak yang baik dan tidak meresahkan, dan sebelumnya terdakwa juga tidak memiliki riwayat kenakalan ataupun pelanggaran hukum.

b) Akibat perbuatan terdakwa

Akibat dari perbuatan terdakwa mengakibatkan masyarakat resah dan saksi korban mengalami trauma seumur hidup.

Berdasarkan penjelasan di atas menurut penulis sanksi pidana 2 (dua) tahun dan 6 (enam) bulan sudah cukup berat bagi terdakwa anak mengingat perbuatan terdakwa juga telah mengakibatkan trauma bagi korban, apalagi terdakwa melakukan tidak hanya sendiri melainkan bekerjasama dengan teman-teman terdakwa lainnya. Hakim dalam memutuskan sanksi juga saling mengedepankan keadilan bagi terdakwa dan korban, melihat bahwa terdakwa ialah seorang anak yang masih dibawah umur. Tentunya dalam penerapan sanksi yang telah diputus oleh Pengadilan, Hakim mempertimbangkan beberapa hal dan dalam pertimbangan tersebut dipenuhi dengan kehati-hatian apalagi hal ini menyangkut kasus tentang anak. Dan sanksi yang diberikan juga ditujukan untuk memberikan efek jera terhadap anak untuk tidak mengulangi perbuatannya lagi dimasa depan, dan menghindari bertambah banyaknya pelaku percobaan perkosaan.

2. Putusan Pengadilan Negeri Maros Nomor 82/Pid.B/2014/PN.Mrs.

Pada kasus kedua Putusan Nomor. 82/Pid.B/2014/PN.Mrs terdakwa Suhartanto bin Usman dijatuhi sanksi Pidana Penjara selama tahun 4 (empat) bulan. Perbuatan terdakwa terbukti secara sah dan meyakinkan melanggar ketentuan Pasal 285 KUHP jo. Pasal 53 ayat (1) KUHP yang mana terdapat unsur-unsur sebagai berikut:

a. Barang Siapa yaitu terdakwa Suhartanto sebagai pelaku tindak pidana

b. Dengan kekerasan atau dengan ancaman kekerasan memaksa seorang wanita untuk melakukan persetubuhan dengan dirinya diluar perkawinan yang dilakukan terdakwa dengan mencekik leher korban hingga terjatuh dengan sebelah tangan dan sebelah tangannya lagi menutupi mulut korban agar tidak berteriak, dan terdakwa mengakui ingin menyetubuhi korban didepan pengadilan. 
c. Tidak selesainya pelaksanaan itu bukan semata-mata disebabkan karena kehendaknya sendiri yaitu ketika terdakwa ingin menyetubuhi korban dalam keadaan pingsan tiba-tiba saksi Fajar menarik tubuh terdakwa keluar dari rumah dan menyerahkan kepada pemerintah setempat.

Selain telah memenuhi unsur-unsur tersebut, hakim juga memiliki beberapa pertimbanganpertimbangan antara lain:

a. Hasil penelitian kemasyarakatan dari pembimbing kemasyarakatan menyatakan faktor terdakwa melakukan perbuatan tersebut disebabkan lingkungan pergaulan terdakwa, terdakwa sering menonton film porno bersama teman-temannya, terdakwa kurang pengawasan dari orang tua.

b. Selama pemeriksaan tidak ditemukan adanya alasan pemaaf maupun pembenar, maka terdakwa harus mempertanggung jawabkan perbuatannya secara hukum.

c. Terdakwa mampu bertanggung jawab, maka dapat dinyatakan bersalah dan dikenakan sanksi pidana.

d. Hakim melihat dan menimbang pada hal yang memberatkan yang mana perbuatan terdakwa mengakibatkan saksi korban mengalami luka dan hal yang meringankan yaitu terdakwa mengakui perbuatannya, belum pernah dihukum, dan seorang anak yang masih perlu bimbingan kedua orang/tua, dan terdakwa beserta saksi korban sudah berdamai.

Pada kasus ini, hakim sependapat dengan tuntutan pertama yang diajukan oleh penuntut umum yaitu dikenakan Pasal 285 KUHP jo. 53 ayat (1). Namun dalam menjatuhkan sanksi pidana penjaranya, hakim tidak sependapat dengan penuntut umum yang menuntut dijatuhkan pidana penjara selama 6 (enam) bulan dan masa percobaan 1 (satu) tahun. Hakim lebih memilih untuk menjatuhkan pidana penjara terhadap terdakwa selama 4 (empat) bulan. Hal tersebut tentu tidak terlepas dari pertimbangan-pertimbangan Hakim baik yuridis maupun non yuridis. Berikut penjelasan mengenai pertimbangan-pertimbangan Hakim dalam menjatuhkan pidana terhadap kasus ini, yaitu:

1) Pertimbangan Yuridis

Pertimbangan yuridis oleh Hakim terhadap Putusan Nomor. 82/Pid.B/2014/PN.Mrs, sebagai berikut:

a) Dakwaan penuntut umum;

b) Keterangan terdakwa;

c) Keterangan saksi;

d) Barang-barang bukti; dan

e) Pasal-Pasal dalam peraturan hukum pidana.

Berdasarkan pertimbangan yuridis di atas, Hakim menjatuhkan sanksi pidana penjara terhadap terdakwa yaitu 4 (empat) bulan. Mengingat ancaman sanksi pidana penjara anak yang melakukan percobaan perkosaan adalah 4,5 tahun, maka sanksi yang diberikan hakim secara normatif telah sesuai dengan aturan undang-undang dan tidak melebihi batas maksimal hukuman.

2) Pertimbangan Non Yuridis

Pertimbangan non yuridis terhadap Putusan Nomor. 82/Pid.B/2014/PN.Mrs, antara lain:

a) Latar belakang terdakwa

Terdakwa melakukan perbuatan pidana dikarenakan beberapa faktor diantaranya ialah karena lingkungan pergaulannya, setelah dilakukan penelitian oleh BAPAS ditemukan fakta bahwa terdakwa sering menonton film porno dengan teman-temannya. Hal tersebut yang mengakibatkan anak berperilaku menyimpang, ini juga disebabkan karena kurangnya pengawasan serta bimbingan dari orang tua. Peran orang tua dalam perkembangan anak sangatlah penting dan sangat berpengaruh karena anak dalam tahap pendewasaan sangat rentan terhadap sikap dan prilaku yang buruk jika tidak diimbangi pengawasan oleh orang tua. 
b) Kondisi terdakwa

Terdakwa merupakan seorang anak yang masih dibawah umur yang masih dalam tahap menuju pendewasaan. Terdakwa sebelumnya tidak pernah di hukum atau melakukan tindak pidana, dan terdakwa juga telah mengakui kesalahan serta menyesal telah melakukan perbuatan tersebut. Terdakwa memiliki itikad baik dengan meminta maaf serta tidak ingin mengulangi perbuatannya lagi. Setelah dilakukan pembicaraan terdakwa dan korban sudah berdamai.

c) Akibat perbuatan terdakwa

Perbuatan terdakwa menjadi pembicaraan masyarakat luas dan meresahkan masyarakat, mengingat seorang anak telah melakukan percobaan perkosaan. Selain itu, saksi korban mengalami luka-luka akibat kekerasan yang terdakwa perbuat.

Berdasarkan pertimbangan non yuridis diatas maka dapat disimpulkan, bahwa hakim dalam memutuskan perkara atau menjatuhi sanksi pidana mempertimbangkan hal-hal yang memberatkan dan juga hal-hal yang meringankan. Tidak berbeda jauh dari Penuntut Umum yang menuntut sanksi penjara selama 6 (enam) bulan, hakim memberikan keringanan dengan menurunkan sanksi sebanyak 4 (empat) bulan saja. Tentu hakim dalam memutuskan putusan telah melewati pertimbangan-pertimbangan dengan hati-hati, hal ini terkait juga dengan terdakwa anak dibawah umur. Menurut penulis putusan hakim pada kasus ini yang menjatuhkan sanksi pidana selama 4 (bulan) dilihat dari sisi perbuatannya tentu masih sangat jauh untuk mengganti kerugian dengan apa yang terdakwa lakukan. Meskipun perbuatan terdakwa tidak selesai atau masih dalam tahap percobaan dan terdakwa merupakan anak dibawah umur, akan tetapi perbuatan tersebut telah melanggar asusila dan aturan hukum baik secara negara maupun agama. Seorang anak yang sudah pernah melakukan perbuatan tersebut dikhawatirkan akan mengulangi perbuatan yang sama di kemudian hari. Maka untuk mencegah anak-anak lain melanggar hukum, perlu diberikan teguran yang keras dengan memberikan sanksi pidana yang sekiranya juga dapat memberikan efek jera terhadap terdakwa sendiri maupun kepada masyarakat luar. Melihat dari pertimbangan-pertimbangan hakim dan kronologi kejadian penulis lebih setuju dengan tuntutan yang diberikan penuntut umum, yaitu sanksi pidana penjara selama 6 (enam) bulan. Dengan waktu tersebut diharapkan terdakwa dapat mengkoreksi diri atas apa yang telah dia perbuat.

Dari analisis kasus diatas maka proses penegakan hukumnya dilakukan sebagai berikut:

1. Hukum itu sendiri

Maksudnya hukum itu sendiri adalah mengenai aturan hukumnya. Aturan hukum ini merupakan titik awal dalam proses penegakan hukum. Aturan yang dimaksud ialah aturan undang-undang yang telah dibuat oleh pemerintah. Sebagaimana dari ketiga kasus tersebut, terdakwa dianggap sah dan meyakinkan telah melakukan tindak pidana percobaan perkosaa dengan dikenakan Pasal 289 KUHP dan Pasal 285 KUHP jo. Pasal 53 ayat (1) KUHP.

\section{Pengakan Hukum}

Penegakan hukum yang dimaksud ialah aparat penegak hukum dibidang kepolisian, kejaksaan, kehakiman, dan lembaga pemasyarakatan. Pada kedua kasus tersebut peran kepolisian, kejaksaan dan kehakiman sangat berpengaruh dan saling terikat satu sama lain guna melakukan penegakan hukum terhadap pelaku yang telah melanggar aturan hukum. Pada ketiga kasus diatas para penegak hukum telah melakukan tugasnya dengan baik, dengan melakukan tindakan pemeriksaan, mengumpulkan bukti-bukti untuk menentukan bahwa terdakwa yakin telah bersalah, hingga akhirnya hakim menentukan putusan bagi terdakwa.

\section{Sarana atau Fasilitas}

Sarana atau fasilitas dalam proses penegakan hukum adalah pengadilan. Pada ketiga kasus tersebut yang mana pelakunya adalah seorang anak yang usianya belum mencapai 18 (tahun) maka pengadilan yang diterapkan kepada anak tersebut dilakukan di Pengadilan 
khusus atau Pengadilan Anak. Sarana atau fasilitas yang diberikan berbeda dengan sarana atau fasilitas terhadap pelaku tindak pidana biasanya (orang dewasa). Dengan adanya pengadilan anak ini dimaksudkan untuk memberikan kenyamanan terhadap anak selama pengadilan berlangsung.

4. Masyarakat

Peran masyarakat sangat membantu dalam proses penegakan hukum. Ketika seorang anak melakukan tindak pidana atau seperti halnya dalam penelitian ini, anak yang melakukan tindak pidana percobaan perkosaan tentu akan dilakukan penelitian oleh Badan Pemasyarakatan (BAPAS). Hasil penelitian dari BAPAS tersebut akan menjadi salah satu pertimbangan hakim dalam memutuskan hasil akhir persidangan. Penelitian tersebut tentu dibutuhkan peran masyarakat untuk memberikan pendapatnya mengenai terdakwa anak tersebut. Peran masyarakat juga sangat berpengaruh untuk membantu pemerintah dalam menanggulangi, mengurangi anak melakukan perbuatan-perbuatan melanggar hukum. Membantu dalam mendidik anak-anak disekitar lingkungannya untuk melakukan hal-hal yang positif.

Penegakan hukum dari kedua kasus diatas, menurut penulis dapat diambil kesimpulan sebagai berikut, pada kasus pertama terdakwa dijatuhi sanksi pidana penjara 2 (dua) tahun 6 (enam) bulan, dan kasus kedua dijatuhi sanksi pidana penjara 4 (empat) bulan. Dari kedua kasus tersebut sama-sama melakukan perbuatan "Percobaan Perkosaan" namun sanksi yang diberikan hakim masing-masing kasus tersebut berbeda-beda. Kedua kasus tersebut dapat dikatakan terjadi disparitas putusan hakim, karena penjatuhan sanksi yang diberikan berbeda-beda.

Disparitas putusan hakim terjadi karena cara pandang dan independensi hakim sendiri, dalam menjatuhkan sanksi hakim tidak boleh di intervensi dari pihak manapun. Menurut penulis kenapa bisa terjadi disparitas putusan, karena hakim sendiri memiliki diskresi dalam menjatuhkan hukuman suatu perkara pidana. Sebagaimana dalam Undang-Undang Nomor 48 Tahun 2009 mengenai kekuasaan kehakiman menyebutkan "bahwa hakim wajib menggali, mengikuti, dan memahami nilai-nilai hukum dan rasa keadilan yang hidup dalam masyarakat" selain itu hakim juga perlu mempertimbangkan latar belakang terdakwa, baik dan jahatnya pada diri terdakwa.

Melihat dari kedua kasus diatas perbedaan penjatuhan sanksi yang dijatuhkan oleh Hakim didasarkan oleh beberapa pertimbangan. Hakim memiliki wewenang untuk menjatuhkan berat dan ringannya sanksi yang didasarkan pada latar belakang terdakwa, perbuatan terdakwa serta mempertimbangkan akibat yang dirasakan atau dialami oleh saksi korban dari perbuatan terdakwa. Meskipun hakim memiliki wewenang atau independensi dalam menjatuhkan sanksi pidana bukan berarti tidak ada batasan. Hakim dalam memutuskan perkara tetap dibatasi sesuai dengan ketentuan yang diatur dalam peraturan perundang-undangan. Meskipun begitu, disparitas tetap bisa terjadi selama belum ada aturan atau pedoman dalam menjatuhkan sanksi pidana. Disparitas akan tetap terjadi dikarenakan jarak antara sanksi pidana minimal dengan maksimal sangat terlampau jauh.

Pertimbangan hakim menjadi salah satu aspek terpenting dalam menentukan keputusan yang dirasa mengandung keadilan. Hakim sebelum menjatuhkan putusan harus memeriksa kembali bukti-bukti yang ada dan hasil selama proses persidangan. Dari kasus kedua hakim menjatuhkan sanksi pidana penjara yang mana kurang dari pada tuntutan penuntut umum. Pengambilan keputusan tersebut disebabkan karena hakim telah memeriksa bukti-bukti dan saran dari hasil penelitian BAPAS sebagai pedoman. Selain itu juga melihat dari lingkungan masyarakat dan kronologis terdakwa yang memang belum sempat menyelesaikan tujuannya. Menimbang hal yang memberatkan dan yang meringankan juga menjadi salah satu pertimbangan hakim dalam memutuskan perkara. Peran orang tua disinilah yang sangat berperan dan berpengaruh dalam mendidik seorang anak, melakukan pengawasan serta membimbing anak untuk tidak terjerumus ke jalan yang salah.

Hakim dalam memutus lebih mengedepankan Resporative Justice dan hati nurani, selain melihat dari akibat yang diterima korban, hakim juga melihat sisi terdakwa. Hakim mengutamakan keadilan bagi terdakwa, apalagi dalam kasus ini terdakwa merupakan seorang anak yang masih memerlukan bimbingan dari orang tua/wali. Meskipun tindak atau perbuatan 
yang dilakukan terdakwa merupakan perbuatan yang keji dan melanggar kesopanan. Hakim tetap perlu mempertimbangkan hal-hal untuk terdakwa anak tersebut, karena seorang anak tetap harus diberikan perlindungan hukum untuk tidak menghilangkan kebebasan dan hakhaknya dalam hidup. Anak merupakan penerus bangsa yang harus dilindungi dan diberikan bekal ilmu yang tepat agar jalan yang ditempuh anak tidak meleset kejalan yang buruk. Penguraian diatas dapat disimpulkan bahwa hakim yang berhak atas perkara yang dihadapkannya, dan hakim berhak memberikan keputusan mengenai peristiwa, hukum, dan pidananya. Keputusan hakim harus dihormati dan dianggap benar.

\section{Simpulan}

Penegakan hukum terhadap anak yang melakukan tindak pidana percobaan perkosaan didasarkan pada ketentuan Undang-Undang Sistem Peradilan Pidana Anak. Seorang anak yang melakukan percobaan perkosaan melanggar ketentuan Pasal 285 KUHP jo. Pasal 53 KUHP dengan ancaman pidana di atas tujuh tahun sehingga upaya diversi tidak dapat dilakukan karena ancaman pidanya lebih dari tujuh tahun. Adapun analisa penegakan hukum terhadap kasus yang dianlisis, kasus pertama dikenakan Pasal 285 KUHP jo. Pasal 53 KUHP dan dijatuhi pidana penjara 2 (dua) tahun 6 (enam) bulan, dan kasus kedua dikenakan Pasal 285 KUHP jo. Pasal 53 ayat (1) dan dijatuhi pidana penjara 4 (empat) bulan. Masing-masing sanksi pidana penjara yang dijatuhkan hakim, lebih ringan dari tuntutan yang diajukan oleh penuntut umum. Adapun pertimbangan hakim dalam menjatuhkan pidana tersebut didasarkan pada pertimbangan yuridis yang meliputi, dakwaan penuntut umum, keterangan terdakwa, keterangan saksi, barang-barang bukti dan pasal-pasal dalam peraturan hukum pidana. Sedangkan pertimbangan non yuridis meliputi, latar belakang terdakwa, kondisi terdakwa dan akibat perbuatan terdakwa.

\section{Daftar Pustaka.}

\section{Buku}

Bambang Waluyo. (2016). Penegakan Hukum Di Indonesia. Jakarta Timur: Sinar Grafika.

Delyana Sahnt. (2004). Konsep Penegakan Hukum. Yogyakarta: Liberty, edisi cetak ulang.

Nyoman Sarikat Putra Jaya. (2005). Kapita Selektra Hukum Pidana. Semarang: Badan Penerbit Undip.

Satjipto Rahardjo. (1980). Hukum, Masyarakat, dan Pembangunan. Bandung: Alumni.

Soerjono Soekanto. (2012). Faktor-Faktor Yang Mempengaruhi Penegakan Hukum. Jakarta: Raja Grafindo Persada.

Romli Atmasasmita. (2000). Sistem Peradilan Pidana: Prespektif Eksistensialisme dan Abolisionisme. Bandung: Binacipta (edisi cetak ulang)

Rusli Muhammad. (2011). Sistem Peradilan Pidana Indonesia. Yogyakarta: UII Press Yogyakarta.

Theodorus Yosep Parera. (2016). Advokat Dan Penegak Hukum. Yogyakarta: Genta.

\section{Jurnal}

Ni Made Dwi Kristiani. (2014). “Kejahatan Kekerasan Seksual (perkosaan) Ditinjau dari Perspektif Kriminologi”. Jurnal Magister Hukum Udayana. Vol.7. No.3.

M. Husein Maruapey. (2017). “Penegakan Hukum dan Perlindungan Negara”. Jurnal Ilmu Politik dan Komunikasi. Vol. 7. No.1.

Sanyoto. (2008.) “Penegakan Hukum Di Indonesia”. Jurnal Dinamika Hukum. Vol.8. No.3.

Tri Wahyu Widiastuti. (2016). “Penegakan Hukum Terhadap Kenakalan Anak”. Journal UNISRI. Vol.1. 
Pusat Kajian Hukum Pidana dan Kriminologi

\section{Regulasi}

Mahkamah Agung Republik Indonesia. Putusan No. 215/Pid.Sus-Anak/2014/PN.Yyk, https://putusan.mahkamahagung.go.id/putusan/a24137acaa01e119c77b593a22b935a2, diakses pada 20 Oktober 2018, pukul 20.25 wib

\section{Website}

TribunJateng.com. (2018). 10 Perssen Kasus Pidana Anak Diselesaikan Secara Pantas. Diakses pada 20 November 2018, http://jateng.tribunnews.com/2018/05/01/hanya-10-persen-kasus-pidanaanak-diselesaikan-secara-pantas

Widia Primastika. (2019). Penyebab Kriminalitas Anak. Diakses pada tanggal 10 Maret, Sumber: https://tirto.id/penyebab-kriminalitas-anak-kurang-kasih-sayang-amp-pengakuan-sosial-cP3F, 